Çağlıyan, V., Attar, M. ve Külahlı, S. (2021). “Dönüşümcü Liderliğin, Örgütsel İnovasyon Üzerindeki Etkisinde Örgütsel Öğrenmenin Aracı Rolü”, Eskişehir Osmangazi Üniversitesi iỉBF Dergisi, 16(1), 124 - 145.

Doi: 10.17153/oguiibf.872569

Başvuru: 01.02.2021

Kabul: 28.02.2021

Araştırma Makalesi/Research Article

\title{
Dönüşümcü Liderliğin, Örgütsel İnovasyon Üzerindeki Etkisinde Örgütsel Öğrenmenin Aracı Rolü
}

\begin{tabular}{|c|c|}
\hline & $\begin{array}{c}\text { Vural Çağlıyan } \\
\text { Melis Attar } \\
\text { Safa Külahlı (D) }\end{array}$ \\
\hline $\begin{array}{l}\text { Dönüşümcü Liderliğin, Örgütsel İnovasyon Üzerindeki } \\
\text { Etkisinde Örgütsel Öğrenmenin Aracı Rolü }\end{array}$ & $\begin{array}{l}\text { The Mediating Role of Organizational Learning in The } \\
\text { Effect of Transformational Leadership on } \\
\text { Organizational Innovation }\end{array}$ \\
\hline Öz & Abstract \\
\hline $\begin{array}{l}\text { Rekabetçi çevre koşulları, işletmeleri, rakiplerine } \\
\text { üstünlük sağlayabilmeleri açısından daha esnek ve } \\
\text { alternatif stratejileri belirleyebilecek yapıya sahip olmaya } \\
\text { zorlamaktadır. Liderlik; yoğun rekabet koşullarında } \\
\text { işletmeleri geleceğe taşıyacak vizyonu inşa etmeye } \\
\text { yardımcı olan stratejik düşünmede ve bunun } \\
\text { organizasyon içerisinde bir kültür olarak yerleşmesinde } \\
\text { önemli rol üstlenmektedir. Liderliğin, yenilikçilik ve } \\
\text { öğrenme üzerinde etkilerini analiz etmek amacıyla, bu } \\
\text { çalışmada modern liderlik yaklaşımlarından dönüşümcü } \\
\text { liderliğin, örgütsel inovasyon üzerindeki etkisinde } \\
\text { örgütsel öğrenmenin aracı rolü incelenmiştir. Bulgular } \\
\text { dönüşümcü liderlik ile örgütsel öğrenmenin, örgütsel } \\
\text { inovasyon üzerinde pozitif yönlü ve anlamlı bir etkisi } \\
\text { olduğunu ve örgüt-sel öğrenmenin dönüşümcüliderlik ile } \\
\text { örgütsel inovasyon arasında kısmı aracılık rolü } \\
\text { üstlendiğini göstermektedir. }\end{array}$ & $\begin{array}{l}\text { Competitive environmental conditions force businesses } \\
\text { to have a structure that can determine more flexible and } \\
\text { alternative strategies to gain an advantage over their } \\
\text { competitors. Leadership: It plays an important role in } \\
\text { strategic thinking that helps to build the vision that will } \\
\text { carry businesses to the future in conditions of intense } \\
\text { competition and its establishment as a culture within the } \\
\text { organization. To analyze the effects of leadership on } \\
\text { innovation and learning, this study examines the } \\
\text { mediating role of organizational learning in the effect of } \\
\text { transformational leadership on organizational } \\
\text { innovation, one of the modern leadership approaches. } \\
\text { The findings show that transformational leadership and } \\
\text { organizational learning have a positive and significant } \\
\text { effect on organizational innovation, and organizational } \\
\text { learning plays a partial mediating role between } \\
\text { transformational leadership and organizational } \\
\text { innovation. }\end{array}$ \\
\hline $\begin{array}{l}\text { Anahtar Kelimeler: Dönüşümcü Liderlik, Örgütsel } \\
\text { İnovasyon, Örgütsel Öğrenme }\end{array}$ & $\begin{array}{l}\text { Keywords: Organizational Innovation, Organizational } \\
\text { Learning, Transformational Leadership }\end{array}$ \\
\hline JEL Kodları: M00, M10, M19 & JEL Codes: M00, M10, M19 \\
\hline \multicolumn{2}{|c|}{$\begin{array}{l}\text { Araştırma ve Bu çalışma bilimsel araştırma ve yayın etiği kurallarına uygun olarak hazırlanmıştır. } \\
\text { Yayın Etiği } \\
\text { Beyanı }\end{array}$} \\
\hline \multicolumn{2}{|c|}{ Çalışmanın tamamı üç yazar ile birlikte/bölümleri yazarlara paylaştırılarak oluşturulmuştur. } \\
\hline \multicolumn{2}{|c|}{ Yazarlar açısından ya da üçüncü taraflar açısından çalışmadan kaynaklı çıkar çatışması bulunmamaktadır. } \\
\hline
\end{tabular}

\footnotetext{
1 Prof. Dr., Selçuk Üniversitesi, IïBF, İşletme Bölümü, vcagliyan@selcuk.edu.tr

${ }^{2}$ Dr. Öğr. Üyesi, Selçuk Üniversitesi, iỉBF, Uluslararası Ticaret Bölümü, melisattar@yahoo.com

3 Öğr. Gör., Selçuk Üniversitesi Kadıhanı Faik İçil Meslek Yüksekokulu, Yönetim ve Organizasyon, safa.kulahli@selcuk.edu.tr
} 


\section{Giriş}

Günümüz rekabet koşullarında işletmeler ayakta kalabilmek için, yeniliklere açık olmalı, sürekli değişen çevre koşullarına uyum sağlayabilecek ve değişimin gerekliliğini tahmin edecek bir örgüt yapısının kurulmasını sağlamalıdırlar. Örgütsel öğrenme ve örgütsel inovasyon kabiliyetini geliştiren işletmeler, sürekli değişen ve gelişen rekabet ortamı koşullarını öngörüp, uyum sağlayarak, rakiplerine nazaran üstünlük sağlayabilirler. Bu sayede küreselleşen pazarlarda her geçen gün yeni bir rakiple karşılaşan ya da mevcut rekabet ortamındaki zorluklarla mücadele eden işletmeler rekabet avantajı sağlayacak seçenek ve yöntemler geliştirebilirler. Bu bağlamda işletmeler kaynaklarının verimliliğini en üst seviyeye çıkartarak, pazardaki değişimlere etkin bir şekilde cevap verecek duruma gelebilirler.

Değişen ve dönüşen rekabet koşullarında işletmeler pazar ihtiyaçlarına cevap verirken, geçmişteki tecrübelerin tüm örgüt çalışanları tarafından içselleştirilmesi ve bireyden ziyade örgütsel öğrenme sayesinde ürün ve hizmet sunumunda yeni fikir ve uygulamaları ortaya koymak zorundadırlar. Özellikle teknolojik güdümlü kuruluşların, hayatta kalmak, rekabet etmek, büyümek ve lider olmak için öncekinden daha yaratıcı ve yenilikçi olmaları gerekir (Gumusluoglu ve Ilsev, 2009: 514). Bu özelliklere sahip bir işletme, zorlu koşullar ile mücadelede öğrenmeyi teşvik etmek için gerekli koşulları oluşturan bir kültür üretir (Waruvu, 2020: 380). Dönüşümcü liderler daha iyi bir performansı teşvik eden bu kültürün oluşmasında önemli bir role sahiptirler. Örgütsel öğrenmeyi bir kültür haline getiren işletmeler için dinamik çevre koşullarına uyum sağlamak ve değişimi yönetmek daha kolay olacaktır. İşletmelerde değişimin ve yeniliğin sağlanabilmesinde liderlerin rolü büyüktür. Yenilik açısından değerlendirildiğinde dönüşümcü liderlerin farklı düşünme ve ileri görüşlülüğü, çalışanlara inovasyon stratejisi geliştirme süreçlerinde katkı sağlamaktadır (Yıldırım vd., 2018: 214). Dönüşümcü liderler değişime odaklıdır. Liderlerin işletmelerin ihtiyacı olan değişimi öngörmesi, işletme dönüşümünü planlaması ve bu geçişi yönetmesi beklenir. Bu dönüşümün sağlanması için gerekli yeniliklerin gerçekleştirilmesi gerekir. Bu yeniliklerin de performansa katkısının olması beklenir. Dönüşümcü liderliğin, işletmelerin performansı ve yenilik üzerindeki etkisi çeşitli akademik çalışmalarda incelenmiştir. Yapılan çalışmalar incelendiğinde dönüşümcü liderliğin, örgütsel inovasyon veya örgütsel öğrenme üzerinde etkisi olduğuna dair sonuçlara ulaşılmaktadır.

Bu çalışmada gerçek bir çalışma ortamında bu değişkenlerin arasındaki ilişkiler ve örgütsel öğrenmenin, dönüşümcü liderlik ve örgütsel inovasyon üzerindeki aracilık rolü incelenmektedir. Bu bağlamda kavramsal bir yapı içerisinde literatürde yapılan çalışmalar incelenerek araştırmanın hipotezleri belirlenmiştir. Daha sonra araştırmanın modeli kurularak araştırma yöntemi hakkında bilgiler verilmiştir. Son olarak elde edilen bulgular açıklanarak, sonuçlar yorumlanmıştır.

\section{Kavramsal Çerçeve}

\section{1. Dönüşümcü Liderlik}

Köklü bir değişimi ifade eden dönüşüm, organizasyonel anlamda, süreçlerin değiştirilerek daha farklı hale gelmesini ifade eder. İşletmenin dış çevresindeki güçlerin etkisi ile başlayan dönüşüm, işletmenin iç çevresel sistemindeki unsurların (vizyon, strateji, yapı vb.) tekrar dizayn edilmesiyle ve yeni bir işletme kültürünün oluşturulmasıyla devam eder (Temel, 2016: 38). Yoğun rekabet ortamındaki dönüşümler, yönetim alanında da dönüşümü zorunlu kılmıştır. Örgüt yönetimleri, ya bu alandaki dönüşümlere ayak uydurmalı ya da dönüşümleri 
kendileri gerçekleştirmelidirler. Uzun vadeli ve vizyon temelli motivasyonel süreçleri vurgulayan dönüşümcü liderlik teorisi 1985 yılında Bernard M. Bass tarafından geliştirilmiştir (Jung vd., 2003: 530). Teori; takipçilerine, örgütün iyiliği uğruna kişisel çıkarlarını aşmaları için ilham veren ve onların üzerinde derin ve benzersiz bir etki yaratmakta yetenekli olan dönüşümcü liderlerin, bireyleri heyecanlandırma ve harekete geçirme yeteneğine sahip olduğunu savunmaktadır (Attar, 2014: 3). Dönüşümcü liderlik sayesinde çalışanlara kazandırılan yeni ve farklı bakış açısı ile yeniliğin, değişimin ve sürekli gelişmenin gerekliliğini benimsemeleri sağlanır ve bu sayede çalışanlar motive edilerek ortaya yeni fikirlerin çıkması sağlanacaktır.

Dönüşümcü liderlik çok boyutlu bir yapı olarak kavramsallaştırılmıştır (Bass, 1985). Bu boyutlar; bireysel ilgi, entelektüel uyarım, ilham verici motivasyon ve ideal etki olarak belirtilmiştir (Bass ve Avolio, 1993: 112). Bu dört boyut, dönüşümcü liderlerin davranışlarını dikkate alarak kavramsal yapıyı oluşturmaktadır. Bireysel ilgi açısından lider, her ekip üyesi ile birebir ilişki kurmaktan, endişeleri dinlemek ve bireysel intiyaçları ele almaktan sorumludur (Dionne Shelley, 2004: 177). Bu anlamda lider, takipçilerinin her birinin kişisel yapılarını dikkate alarak, onların istek, ihtiyaç ve sorunları ile tek tek ilgilenerek her birinin organizasyon için değerli olduğunu hissettirmektedir (Temel, 2016: 46). Bu ilgi ve kişiye özel davranış sayesinde lider takipçileri açısından bir kılavuz olarak algılanmakta, bu algı da çalışanların özgüvenlerini artırarak iş yapma süreçlerinde daha aktif ve verimli olmalarını sağlamaktadır (Bass ve Riggio, 2006: 7). Entelektüel uyarım yoluyla, lider, takipçilerine gerekli kaynakları sağlar ve onları farklı çalışmalara teşvik eder (Avolio vd., 1999: 444). Bu sayede çalışanlar mevcut sorunlara geleneksel bir yaklaşımla değil, sorunun altında yatan esas sebeplere odaklanarak farklı çözümler bulmaya yönelirler. İlham verici motivasyon sayesinde, bir lider sadece gelecek için bir vizyona sahip olmakla kalmaz, aynı zamanda hedeflere ulaşmanın yolunu gösterir ve takipçilerinin bunu yapabildiklerini anlamalarına yardımcı olur (Jaiswal ve Dhar, 2015: 31). Bu yaklaşım çalışanların kendilerine daha çok güvenmelerine vesile olarak motivasyonlarını artırır. İş ve süreçlere daha iyi odaklanarak daha fazla katkı yapmalarını sağlar. İdeal etki boyutu, çalışanlar ile lider arasında güçlü bir duygusal bağı ifade eden "karizma" ile ele alınmıştır. Liderler izleyenleri tarafından olağanüstü yeteneklere sahip kararlı ve azimli kişiler olarak algılanmaktadır (Bass, 1985: 5). Bu sayede izleyenler liderlerine saygı duymakta ve onları kendilerine örnek almaktadırlar. Liderler bu sayede izleyenlerine ortak bir amaç doğrultusunda çalışma azim ve kararlııı̆ını yükleyerek onları etkilemektedirler.

Yazında dönüşümcü liderlik konusunda yapılan araştırmalara bakıldığında, dönüşümcü liderliğin inovasyon, bireysel anlamda yaratıcılık, örgütsel öğrenme gibi faktörler üzerinde etkili olduğunu gösteren birçok araştırmaya rastlamak mümkündür. Şentürk vd. (2016: 173), dönüşümcü ve etkileşimci liderliğin çalışanların bireysel inovasyon yeteneklerine etkisini belirlemeye yönelik yaptıkları çalışmalarında dönüşümcü liderliğin alt boyutlarında olan ideal ekinin bireysel yenilikçilik üzerinde pozitif yönlü bir etkisi olduğunu belirtmişlerdir. Aga vd. (2016: 806), dönüşümcü liderliğin proje başarısı üzerindeki etkisini ve ekip kurmanın bu etkideki aracılık rolünü inceleme amacıyla, Etiyopya Sivil Toplum Örgütlerinin 200 kalkınma proje yöneticisi üzerindeki yapılan araştırma sonuçlarını analiz ederek dönüşümcü liderliğin proje başarısında pozitif yönlü bir ilişki olduğunu ve ekip kurmanın bu ilişkide aracı rolü üstlendiğini belirtmişlerdir. Dong vd. (2017: 439) takım liderlerinin hem bireysel hem de takım yaratıcılığını geliştirmedeki zorluklarını ele aldıkları araştırmalarında, çift odaklı dönüşüm liderliğini ve yaratıcılığı birleştiren çok düzeyli bir model geliştirip test etmişlerdir. Bireysel 
üyelerden, ekip liderlerinden ve doğrudan üst düzey yöneticilerden gelen anket verilerini kullanarak, bireysel odaklı dönüşümcü liderliğin, bireysel beceri geliştirme yoluyla bireysel yaratıcılığa olumlu bir etkisi olduğunu, takım odaklı dönüşümcü liderliğinin de takım yaratıcılığını etkilediğini ifade etmişlerdir. Polatçı ve Sobacı (2017: 27) Türkiye'deki bir bankanın üst düzey yöneticileri üzerinde liderlik özellikleri ve çatışma yönetimi yeteneği üzerinde bir araştırma yapmışlardır. 309 şube müdüründen elde edilen verilere göre çatışma yönetiminde uygulanan stratejilerin belirlenmesinde etkileşimci ve dönüşümcü liderlik özelliklerinin etkili olduğunu ifade etmişlerdir. Bomah vd. (2018: 180), hemşire yöneticilerinin dönüşümsel liderlik davranışlarının iş tatmini ve hasta güvenliği sonuçları üzerindeki etkilerini incelemişlerdir. 378 hemşire yöneticisi üzerinde yaptıkları araştırmada dönüşümlü liderlik davranışlarının, hastalar ve hemşireler için güvenli işyeri koşulları yaratmada yararlı bir strateji olacağını ortaya koymuşlardır. Dönüşümcü liderlerin, takipçilerinin işlerini daha fazla sahiplenmelerini sağlayacak şekilde hareket etmesi beklenir. Hetlant vd. (2018: 746), dönüşümsel liderliğin, iş taleplerini ve iş kaynaklarını optimize etmeyi amaçlayan, takipçilerin iş yapma davranışına yönelik proaktif davranışlarıyla pozitif ilişkili olduğu varsayımıyla yaptıkları araştırmada, dönüşümcü liderlerin, takipçilerinin iş yapma isteklerini olumlu yönde etkileyeceği ve terfi sisteminin bu etkiyi kolaylaştıracağı sonucuna varmışlardır. Yapılan bu çalışmalara da bakıldığında dönüşümcü liderlik, çalışanların daha özverili davranmalarını sağlayarak verimliliklerini artırmakta, moral ve motivasyonlarını olumlu yönde etkilemektedir. Işletme açısından bakıldığında da örgütsel etkinliğin ve kişi örgüt uyumunu da artırdığı ifade edilebilir.

\section{2. Örgütsel İnovasyon}

Inovasyon, (yenilik), bilim ve teknoloji çalışmalarında ortak bir dil geliştirmek için yayınlanan Oslo Kılavuzu'nda (OECD, 2005); “iş̧letme içi uygulamalarda, iş yeri organizasyonunda, dış ilişkilerde yeni veya önemli derecede iyileştirilmiş bir ürün (mal veya hizmet) veya süreç, yeni bir pazarlama yöntemi ya da yeni bir organizasyonel yöntemin gerçekleştirilmesidir." Amabile vd. (1996: 1155) inovasyonu, yaratıcı fikirlerin bir organizasyon içinde başarılı bir şekilde uygulanması olarak tanımlamaktadır. İnovasyon özellikle büyük ve köklü kuruluşlarda rekabet avantajını sürdürmede önemli konulardan biri haline gelmiştir (Ellonen, 2008: 160). Günümüzde özellikle bilgi-işlem teknolojisi endüstrisi gibi ileri teknoloji segmentlerinde gelirin yarısı beş yaşından küçük ürün ve hizmetlerden kaynaklanmaktadır (Wang ve Ahmed, 2004: 303). Literatürde inovasyon ve alt faktörleri ile ilgili birçok çalışma yapılmıştır. İnovasyon kavramı, inovasyon eğilimi, inovasyon yeteneği, örgütsel inovasyon gibi farklı şekillerde araştırmalara konu olmuştur. İnovasyon alanında yapılan araştırmalarda inovasyon tanımlamaları farklı şekillerde ortaya çıkmıştır. Kimi araştırmacılar, inovasyonu bir süreç olarak tanımlayıp, ortaya çıkışından örgütün bir parçası haline gelinceye kadar olan süreci incelerken, kimi araştırmacılar ise inovasyonun bir sonuç olduğunu ve bunun hangi şart ve ortamlar altında ortaya çıktığını araştırmışlardır (Özdevecioğlu ve Biçkes, 2012: 25). Bu bağlamda inovasyon, yönetsel (pazar, örgütsel yapı inovasyonu vb.) ve teknik inovasyon (ürün, süreç inovasyonu vb.) olarak gruplandırılmaktadır. İnovasyon-performans ilişkisi üzerine yapılan çok fazla araştırma olmasına rağmen, önceki araştırmalar esas olarak bir tür inovasyona, yani teknolojik inovasyona odaklanmıştır (Damanpour ve Aravind, 2011: 423). Bununla birlikte, Damanpour ve Aravind (2011: 424), tek bir inovasyon türünün hatta "sadece bir tür" inovasyon setinin benimsenmesinin, işletmelerin inovasyonun performans üzerindeki olumlu etkilerini tam olarak anlamalarını sağlayamayacağını savunmuşlardır. Bazı 
araştırmalarda örgütsel inovasyon, teknolojik inovasyonun verimli kullanılmasının ön şartı ve kolaylaştırıcısı olarak kabul edilmiştir (Azar ve Ciabuschi, 2017: 324).

Örgütsel inovasyon, organizasyonel bağlamda değerli ve faydalı yeni ürün / hizmetlerin yaratılmasıdır (Woodman vd., 1993: 293). Bir başka ifade ile organizasyonların maliyetlerini azaltmak, çalışan memnuniyetini artırarak verimliliği artırmak için benimsenen yeni bir yönetim şeklini oluşturmaktır (Yiğit, 2015: 2). Çevresel değişime verilen yanıtlar veya bir organizasyonda değişime yol açma araçları olarak ifade edilen örgütsel inovasyon ile kuruluşlar, yalnızca yeni teknolojiyi uygulayarak değil, aynı zamanda teknik ya da idari değişiklikleri kuruluş amaçlarına ulaşma düzeyini artıran organizasyon yapılarına başarıyla entegre ederek çevresel değişimler ve belirsizlikler ile başa çıkabilirler (Damanpour ve Evan, 1984: 393).

Bu çalışmada inovasyon süreç ve sonuç bakımından kapsayıcı bir şekilde ele alınarak örgütün inovasyon yetenekleri değerlendirilecektir. Örgütsel inovasyon literatürde farklı çalışmalarda birbirine benzer alt boyutları ile incelenmiştir. Wang ve Ahmet (2004: 304) örgütsel inovasyonu ürün, pazar, süreç, davranış ve stratejik inovasyon olmak üzere beş alt boyutta incelemektedir.

Ürün inovasyonu, müşterilerin ihtiyaç, istek ve beklentilerini karşılama amacıyla yeni ürün ve hizmetlerin geliştirilmesi ya da mevcut ürün ve hizmetleri iyileştirerek sunulmasını ifade etmektedir (Damanpour, 1996:698). Süreç inovasyonu, üretim, hizmet veya idari operasyon yöntemlerinin oluşturulmasını veya iyileştirilmesini ve yeni ürünler geliştirmek için gerçekleştirilen süreç, sistem ve yeniden yapılandırma faaliyetlerindeki gelişmeleri içerir (Oke, 2007: 738). İşletme için değer yaratan yeni rekabetçi stratejilerin geliştirilmesi olarak ifade edilen strateji inovasyonu, işletmelerin çevresel etkileşimlerimi dikkate alarak değişimleri kontrol etmeyi amaçlar (Wang ve Ahmet, 2004:305). Ali vd. (1995: 57) inovasyonun pazar temelli bir yapıda olduğunu ifade ederek inovasyonu; ürünlerin benzersiz olması veya ürün yeniliği açısından tanımlamaktadır. Bu bağlamda pazar inovasyonu, bir ürünün tasarımından fiyatlandırılmasına kadar birçok konuda yapılan yenilik ve değişikliklerin yönetilmesi olarak ifade edilmektedir (Ali vd., 1995: 58).

Örgütsel inovasyon, alt boyutları da dikkate alındığında yazında birçok çalışmaya konu olmuştur. Bununla birlikte işletmelerin günümüz rekabet koşullarında ayakta kalmasını sağlayacak bu yenilik çalışmalarının hangi faktörler tarafından etkilendiği de kavramsal ve deneysel olarak araştırmalara konu olmuştur. Fay vd. (2015: 261), imalat sektöründe faaliyet gösteren işletmeler üzerinden yaptıkları araştırmalarda, üretim personeli ve idari personel örgütlenmesinin örgütsel inovasyonu ne derecede etkilediğini ve insan kaynakları yönetim sistemlerinin ekip çalışması ve inovasyon ilişkilerini geliştirip geliştirmediği belirlemeye çalışmışlardır. Sonuçlar, ekip çalışmasının kuruluşlarda daha yaygın kullanılmasının örgütsel inovasyon seviyesinin yükselttiğini göstermektedir.

Azar ve Ciabuschi (2017: 324), örgütsel ve teknolojik inovasyonun işletme ihracat performansları üzerindeki etkisine yoğunlaşmıştır. 218 isveçli ihracat işletmesinin verileri üzerinden yaptıkları çalışmalarında, örgütsel inovasyonun teknolojik inovasyonu sürdürerek hem doğrudan hem de dolaylı olarak ihracat performansını artırdığını belirtmişlerdir. AnzolaRomán vd. (2018: 233), örgütsel inovasyonun, iç ve dış kaynaklı yenilik uygulamaları gibi diğer inovasyon faaliyetleriyle birlikte, ürün ve süreç inovasyonu elde etme olasılığını nasıl etkilediğini belirlemeye yönelik bir çalışma yapmışlardı. Sonuçların, örgüt içi Ar-Ge çalışmaları ve dış kaynaklı yenilik uygulamalarının olumlu etkilerinin yanı sıra örgütsel inovasyonun 
teknolojik yeniliklerin gerçekleştirilmesi üzerindeki olumlu bir etkisi olduğunu ifade etmişlerdir. Zuñiga-Collazos (2018: 254), 364 turizm şirketinde örgütsel inovasyonu analiz etmiştir. Turizm şirketlerinin örgütsel inovasyonlarının yönetim, pazarlama ve satış işlemleri üzerinde olumlu etkileri olduğunu belirtmiştir.

\section{3. Örgütsel Öğrenme}

Örgütsel öğrenme, örgütün kendisinin yapısal öğelerine ve sonuçlarına yansıyan bireyler tarafından artan örgütsel arayışlar ve başarılı yeniden yapılanmalar olarak tanımlanabilir (Fiol ve Lyles, 1985: 803). Bir başka tanımda örgüt davranışlarının değiştirilmesi veya geliştirilmesi için işletmelerin, elde edilen veriler ile daha iyi düşünmesi olarak ifade edilmiştir (Garvin, 1993: 80). Sürekli değişen ve gelişen pazar ve rekabet ortamında işletmelerin başarıları kendilerini ayakta tutacak yeni fikir, bilgi ve bunların örgüte yayılmasıyla ortaya çıkacak yeni ürün ve hizmetlere bağlıdır. Bu açıdan öğrenme, değişim süreçlerinde en önemli faktörlerden birisi olarak karşımıza çıkmaktadır (Seçilmiş vd., 2017: 151). İ̧̧letmelerin değişim ve gelişim sürecini yönetebilmeleri için öğrenmenin sürekliliğinin sağlanması ve örgütsel anlamda öğrenme seviyesine ulaşması gereklidir (Avcl ve Küçükusta, 2009: 34). Huber (1991: 91) öğrenme süreci ile alakalı yaptığı literatür araştırmasında, öğrenme sürecinin; bilgi sahibi olunması, bilginin paylaşılması, elde edilen bilgilerden çıkarım yapılması ve bu deneyimlerin saklanması şeklinde gerçekleştiğini ifade etmiştir. Bu aşamalar dikkate alındığında örgütsel öğrenmenin bir süreç olarak değerlendirilmesi aşikârdır.

Öğrenme yönelimi, rekabet avantajını arttırmak için bilgi oluşturma ve kullanmada organizasyon çapında bir aktiviteyi ifade eder (Calantone vd., 2002: 515). Buna, müşteri ihtiyaçları, pazar değişiklikleri ve rakiplerin eylemleri hakkında bilgi edinme ve paylaşmanın yanı sıra rakiplerinden daha üstün yeni ürünler oluşturmak için yeni teknolojilerin geliştirilmesi dâhildir (Hurley ve Hult, 1998: 42). Örgütsel öğrenme kavramını ölçmek için literatürde değişik çalışmalar yapılmıştır. Bu çalışmalar içerisinde Calantone vd. (2002) tarafından yapılan araştırmada örgütsel öğrenmenin dört alt boyutundan bahsedilmektedir. Bu boyutlar; öğrenme ortamını teşvik etmeyi ve öğrenmeye değer vermeyi ifade eden öğrenmeye bağlılık, kuruluş çapında, ortak bir vizyona sahip kişilerce öğrenmeye odaklanmayı ifade eden paylaşılan vizyon, örgütün mevcut işleyişine eleştirel anlamda bakan ve yeni fikirleri benimseyerek teşvik eden açık fikirlilik ve öğrenmenin edinilen bilgilerin farklı departmanlar arası paylaşılması, yorumlanması ve tartışııması ile daha sağlıklı olacağını ifade eden sistem içi bilgi paylaşımıdır (Calantone vd., 2002: 517). Öğrenmeye bağlılık, işletmelerin hayatta kalmaları ve kendilerini geliştirmeleri açısından çok önemli bir yere sahiptir. Bir organizasyon bilginin gelişimini desteklemiyorsa, çalışanlar öğrenme faaliyetlerini sürdürmek için motive olmayacaktır (Calantone vd., 2002: 516). Farklı departmanların bilgi ve tecrübelerinin paylaşılması ve örgütsel olarak bu deneyimlerin içselleştirilmesi de örgütsel öğrenmeye katkı sağlayacaktır. Yenilik ve gelişimin önündeki en büyük engel geleneksel sisteme üstünkörü bağılık ve yeni fikirlere açık olmamaktır. Örgütsel öğrenmenin bir boyutu olan açık fikirlilik özelliği bu engellerin ortadan kalkması için örgütün mevcut sistemine eleştirel bir bakışla da yaklaşabilen ve yeni fikirlere açık olmayı gerektiren bir özelliktir. Bütün bu özellikler ile kazanılan bilgi ve tecrübelerden elde edilen verilerin kaydedilmesi, işlenmesi ve paylaşılmasını öngören sistem içi bilgi paylaşımı boyutu da örgütsel öğrenmeyi bir sistematik haline getirecektir.

Örgütsel öğrenme ile ilgili yapılan araştırmalar incelendiğinde, örgütsel öğrenmenin işletmelere, örgütsel bağlılık ve rekabet avantajı elde etme gibi birçok avantaj sağlayacağı 
görülmektedir. Jerez-Gomez vd. (2005: 719) ölçek geliştirme çalışması kapsamında, 111 İspanyol işletmesi üzerinde yaptıkları araştırmada örgütsel öğrenme boyutlarını, yönetimsel bağlılık, sistem perspektifi, açıklık ve tecrübe, bilgi aktarımı ve entegrasyonu olarak belirlemişlerdir. Alegre ve Chiva (2008: 315), örgütsel öğrenme yeteneğini deney, risk alma, dış çevre ile etkileşim, diyalog ve katılımcı karar verme olmak üzere beş boyutta tanımladıkları çalışmalarında, bu boyutların ürün inovasyon performansı üzerindeki etkisini araştırmışlardır. Seramik karo üreticileri üzerinden yaptıkları araştırmalarının sonuçları örgütsel öğrenmenin inovasyon performansı üzerinde etkili olduğunu göstermiştir. Onağ ve Tepeci (2016: 50), örgütsel öğrenme yeteneği, inovasyon, yeni ürün ve işletme performansı değişkenleri arasındaki ilişkileri incelemek için yaptıkları çalışmalarında; öğrenme yeteneğinin örgütsel inovasyon aracı değişkeni ile yeni ürün ve işletme performansı üzerinde etkili olduğu sonucuna ulaşmışlardır. Demirel ve Tohum (2018: 277), kamu kurumu çalışanlarına yönelik yaptıkları araştırmada örgütsel öğrenme ile örgütsel vatandaşlık davranışı arasındaki ilişkiyi analiz etmişlerdir. Bu analizlerin sonucunda, örgütsel vatandaşlık davranışı ile örgütsel öğrenme arasında pozitif yönlü bir ilişkinin olduğu belirlenmiştir.

\section{4. Dönüşümcü Liderlik, Örgütsel İnovasyon ve Örgütsel Öğrenme Arasındaki ílişkiler}

Literatürde yapılan birçok çalışmada dönüşümcü liderliğin inovasyon üzerindeki etkileri incelenmiştir. Dönüşümcü liderlerin, organizasyon içindeki inovasyonu ve organizasyonların inovasyon eğilimini geliştirdiği ifade edilmiştir (Gumusluoglu ve Ilsev, 2009: 517). Dönüşümcü liderliğin boyutlarından, entelektüel uyarımın ve ilham verici motivasyonun örgütsel inovasyon için kritik bir öğe olduğu vurgulanmıştır (Elkins ve Keller, 2003:587). Jung vd. (2003: 525), üst düzey yöneticilerin liderlik tarzlarının işletmelerin inovasyonuna olan etkilerini incelemek adına yaptıkları çalışmalarında, dönüşümcü liderlik özelliklerine sahip liderlerin örgütsel inovasyonu doğrudan ve olumlu yöne etkilediğini ifade etmişlerdir.

Bir başka çalışmada dönüşümcü liderliğin hem bireysel düzeyde takipçilerin yaratıcılığına hem de örgütsel düzeyde inovasyon üzerindeki etkisine ilişkin bir model sunulmakta ve dönüşümcü liderliğin bireysel ve örgütsel anlamda yaratıcılık üzerinde önemli etkileri olduğu belirtilmektedir (Gumusluoglu ve Ilsev, 2009: 462). 372 çalışan üzerinde yapılan bir araştırmada, dönüşümcü liderlerin, çalışan yaratıcılığını teşvik etmesiyle inovasyon ortamının oluşacağı belirtilmiştir (Jaiswal ve Dhar, 2015: 30). Yıldırım vd. (2018: 213), küçük ölçekli işletmelerin yöneticileri üzerinde, liderlik özelliklerinin inovasyon stratejilerini uygulamada nasıl bir etkiye sahip olduğunu belirlemek amacıyla 149 üst düzey yöneticilerden elde edilen veriler ile bir analiz yapmışlardır. Sonuçlar, bu iki değişken arasında pozitif yönlü ve anlamlı bir ilişkinin olduğunu göstermektedir. Waruwu vd. (2020: 378) Endonezya'daki özel okul öğretmenleri örnekleminde; dönüşümcü liderlik, örgütsel öğrenme ve örgütsel yapının öğretmen inovasyon kapasitesi üzerindeki etkisini ölçmeyi amaçladıkları araştırmalarında; dönüşümcü liderlik, örgütsel öğrenme ve örgütsel yapının yenilik kapasitesi üzerinde olumlu ve anlamlı bir etkiye sahip olduğunu ifade etmişlerdir. Çalışma, bu sonuçlara dayanarak öğrenen organizasyonlar ve organizasyon yapısı açısından, dönüşümcü liderlik yoluyla öğretmen inovasyon kapasitesinin oluşturulması için bir model önermektedir. Lei vd. (2020: 481), dönüşümcü liderliğin bireyler ve kuruluşların inovasyon yeteneği üzerindeki etkilerini araştırmak amacıyla, 330 katılımcıdan elde edilen veriler üzerinden analizler yapmışlardır. Analiz sonuçları hem bireylerin hem de firmaların inovasyon kapasitesini beslemek ve geliştirmek için dönüşümcü liderlik tarzını uygulamanın önemli bir rolü olduğunu göstermektedir. Bu açıdan bakıldığında literatürde yapılan araştırmalar, dönüşümcü liderlik ile 
örgütsel inovasyon arasında pozitif yönlü ilişki olduğunu göstermektedir. Bu varsayımlara dayanarak bu iki değişken arasındaki ilişkinin incelenmesi için $\mathrm{H}_{1}$ hipotezi geliştirilmiştir.

$H_{1}$ : Dönüşümcü liderliğin, örgütsel inovasyon üzerinde pozitif yönlü bir etkisi vardır.

Bu çalışma kapsamında incelediğimiz örgütsel öğrenme ile dönüşümcü liderlik ve örgütsel inovasyon arasındaki ilişkilere yönelik literatürde birçok çalışma yapılmıştır. Bazı çalışmalar dönüşümcü liderlik ile örgütsel öğrenme arasında anlamlı bir ilişki olduğunu göstermiştir (Hsiao ve Chang, 2011: 621). Kark vd. (2003: 246), dönüşümcü liderliğin, benlik kavramlarını organizasyon veya grubun misyonuna bağlayarak, takipçilerinin değerlerini ve özgüvenlerini ele alarak ve değiştirerek onları etkilediğini öne sürmektedir. Hasiao ve Chang (2011: 621) 330 ortaokul öğretmeni üzerinde gerçekleştirdikleri çalışmada dönüşümcü liderliğin örgütsel öğrenme ve inovasyon üzerindeki etkilerini araştırmışlardır. García vd., (2012: 1040) 168 işletme üzerinde yaptıkları araştırmada, dönüşümcü liderlik, örgütsel performans, örgütsel öğrenme ve inovasyon ilişkilerini incelemişlerdir. Dönüşümcü liderliğin, örgütsel performansı örgütsel öğrenme ve inovasyon yoluyla olumlu yönde etkilediğini belirtmişlerdir. Abbasi ve Zamani (2013: 505), İran tarım fakültelerinin performansının iyileştirilmesinde dönüşümcü liderliğin, örgütsel kültürün ve örgütsel öğrenmenin rolünü araştırmak ve onları öğrenen örgütler haline getirmek için bir çalışma gerçekleştirmişlerdir. Sonuçlar bağlamsal bileşenler (dönüşümcü liderlik ve öğrenen örgüt kültürü) ile süreç bileşeni (örgütsel öğrenme) arasında pozitif ve anlamlı bir ilişki olduğunu göstermiştir. Yapılan çalışmalara da bakıldığında dönüşümcü liderliğin, organizasyonun deney, iletişim ve diyalog yoluyla öğrenmesini sağladığını ve öğrenme için gerekli olan uyarımı, kişiselleştirilmiş düşünceyi ve motivasyonu teşvik ettiğini söylemek mümkündür (Sendjaya ve Sarros, 2002: 57). Lashari vd. (2020: 685), Pakistan'daki kamu ve özel bankaların üst ve orta düzey yöneticileri üzerinden yaptıkları araştırmada elde ettikleri verilere göre; dönüşümcü liderlik ile örgütsel öğrenme ve bilgi paylaşımı değişkenleri arasında pozitif yönlü bir ilişkinin olduğunu ifade etmişlerdir. Bahsi geçen çalışmalara ve bu varsayımlara dayanarak dönüşümcü liderlik ile örgütsel öğrenme arasında pozitif yönlü bir ilişkinin olduğunu ifade edebiliriz. Bu bağlamda araştırmanın ikinci hipotezi geliştirilmiştir.

$H_{2}$ : Dönüşümcü liderliğin, örgütsel öğrenme üzerinde pozitif yönlü bir etkisi vardır.

Örgütsel öğrenmenin, inovasyon üzerindeki etkilerini incelemeye yönelik literatürde yapılan birçok araştırma bu değişkenler arasında da bir ilişkinin olduğunu göstermektedir. Inovasyonların temelinde bireysel, grup ya da örgütsel olarak öğrenme sonucu elde edilen yeni bilgilerin etkisi yadsınamaz. Bundan yola çıkarak inovasyonu örgütlerdeki bilginin edinilmesi ve işlenmesi ve yorumlanmasının bir sonucu olarak da görebiliriz. Örgütsel öğrenmenin etkilediği değişkenlerden biri de inovasyon kavramıdır. Liao vd. (2008: 19) Tayvan'da finans ve imalat sektöründen alınan veriler ile bilgi edinme ile inovasyon arasındaki ilişkileri araştırmışlar, öğrenme ile inovasyon arasında anlamlı bir ilişkinin olduğunu ortaya koymuşlardır. Jiménez ve Sanz (2011: 408) 451 İspanyol işletme üzerinde yaptığı araştırmada, örgütsel öğrenme ve inovasyonun, iş performansına olumlu katkıda bulunduğunu ve örgütsel öğrenmenin, inovasyonu etkilediğini ifade etmişlerdir. Liao ve Wu (2010: 1099) yapısal eşitlik modellemesi kullanarak, bilgi yönetimi ile örgütsel öğrenme ve örgütsel inovasyon arasındaki ilişkiyi analiz ettikleri araştırmalarında, örgütsel öğrenmenin bilgi yönetimi ve örgütsel yenilik arasındaki aracı değişken olduğunu belirtmişlerdir. Eshlaghy ve Maatofi (2011: 114), 82 KOBi şirketleri örnekleminde yaptıkları araştırmada; örgütsel öğrenmenin üç boyutu (paylaşılan vizyon, açık fikirlilik ve öğrenmeye bağlılık) ile inovasyon arasında olumlu ve anlamlı bir ilişkiyi 
tespit etmişlerdir. Onağ ve Tepeci (2016: 50), orta ve üst düzeydeki yönetici ve çalışanlar üzerinde yaptıkları araştırmalarında, örgütsel öğrenme yeteneğinin yeni ürün performansı ve örgütsel inovasyon üzerinde etkili olduğunu ve örgütsel öğrenme, örgütsel inovasyon, yeni ürün performansı ve işletme performansı değişkenlerinin birbirlerini önemli düzeyde etkiledikleri belirtilmiştir. Patky (2020: 235), örgütsel öğrenmenin inovasyon ve performans üzerindeki etkisini araştırmak üzere yaptığı literatür araştırmasında 32 araştırmayı incelemiş ve bu çalışmalardaki sonuçlara dayanarak örgütsel öğrenmenin inovasyon üzerinde olumlu yönde etkisinin olduğunu ifade etmiştir. Araştırma sonuçları, işletmelerin performans ve yeni ürün performanslarını arttırabilmelerinin yolunun, örgütsel öğrenme kabiliyeti doğrultusunda artan örgütsel inovasyona ile sağlanacağını göstermiştir. Bu yapılan araştırmaların sonuçları neticesinde araştırmanın üçüncü hipotezi aşağıdaki gibi formüle edilmiştir.

$H_{3}$ : Örgütsel öğrenmenin örgütsel inovasyon üzerinde pozitif yönlü bir etkisi vardır.

Araştırma kapsamında kurulan bu üç hipotez değerlendirilirken, örgütsel öğrenmenin, dönüşümcü liderlik ve örgütsel inovasyon arasındaki ilişkide aracı rol üstlenebileceği varsayımıyla $\mathrm{H}_{4}$ hipotezi geliştirilmiştir.

$H_{4}$ : Dönüşümcü liderliğin örgütsel inovasyon üzerindeki etkisinde örgütsel öğrenmenin aracı rolü vardır.

Bu sonuçlar doğrultusunda araştırmanın modeli Şekil 1'deki gibi oluşturulmuştur.

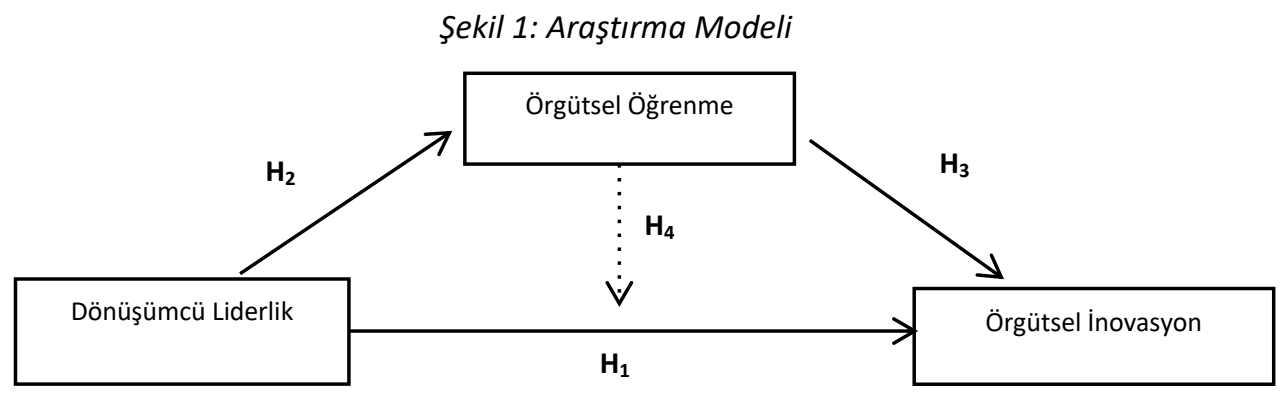

\section{Metodoloji}

\subsection{Araştırmanın Yöntemi}

Araştırmada öncelikle literatür taraması yapılarak değişkenler ile ilgili ilişkiler incelenmiş ve araştırmanın kavramsal yapısı oluşturulmuştur. Literatür taraması sonucu üç değişkenli bir uygulama tasarlanmış ve araştırmanın birincil veriler üzerinden yapılmasına karar verilmiştir. Araştırmada veri toplamak için anket yönteminden faydalanılmıştır. Anket formu dört bölümden oluşmaktadır. Birinci bölümde katılımcıların demografik özelliklerine ilişkin sorular, ikinci bölümde dönüşümcü liderlik, üçüncü bölümde örgütsel inovasyon ve son bölümde örgütsel öğrenme ile ilgili ifadeler yer almaktadır. Ankette yer alan ifadeler $5^{\prime}$ li likert tipi ölçeği referans alarak hazırlanmıştır. Anket ile elde edilen veriler SPSS 22 paket programı ile analiz edilmiştir. Araştırmada elde edilen veriler ve değişkenlerle ilgili güvenilirlik analizi yapılarak, değişkenler arası ilişkileri analiz etmede korelâsyon ve regresyon analizlerinden faydalanılmıştır. 


\subsection{Araştırmada Kullanılan Ölçekler}

Araştırmada üç farklı ölçek kullanılmıştır. Kullanılan ölçeklerin belirlenmesinde literatürdeki çalışmalardaki diğer ölçekler de incelenmiş, çalışmalarda sıkça kullanılan ve güvenilir sonuçlara ulaşılan ölçekler tercih edilmiştir. Literatürde liderlik yaklaşımları ile ilgili birçok farklı çalışma mevcuttur. Liderlik yaklaşımlarından Dönüşümcü liderliği sistematize eden ve literatürde sıklıkla kullanılan iki ölçek mevcuttur. Bunlardan ilki Podsakoff vd. (1990) tarafından yazındaki farklı çalışmalardan derlenerek geliştirilen 5 boyuttan ve 28 maddeden oluşan ölçektir. İkincisi ise literatürde en çok atıf alan çalışmalardan birisi olduğu için bu çalışmada da kullanılan Bass ve Avolio (1995) tarafından geliştirilen ölçektir. Ölçek, 20 ifade ve 5 boyutlu olup çalışanların liderlerinin davranışlarını değerlendirilmesi esasına göre kurgulanmıştır. İlgili ifadelerin oluşturduğu boyutlar aşağıda yer almaktadır:

- 1-4. Ifadeler : İdeal Etki/Atfedilen (IEA)

- 5-8. ifadeler : İdeal Etki/Davranış (IED)

- 9-12. Ifadeler : ilham Verici Motivasyon (IM)

- 13-16. Ifadeler : Entelektüel Uyarım (EU)

- 17-20. Ifadeler : Bireysel ilgi (Bi)

İnovasyon kavramı literatürdeki çalışmalarda inovasyon yeteneği, inovasyon kapasitesi, örgütsel inovasyon gibi farklı yaklaşımlarla araştırmalara konu olmuştur. Bu araştırmada ölçülmesi amaçlanan örgütsel inovasyon kavramı için literatürde öne çıkan ölçeklerden birisi Damanpour vd. (1984) tarafından geliştirilen ölçek, yönetimsel ve teknik inovasyon boyutlarında kategorize edilmiştir. Bir diğer ölçek Jimenez-Jimenez ve Sanz-Valle (2008) tarafından geliştirilen 2 boyutlu ve 4 maddeli ölçektir. Wang ve Ahmet (2004) tarafından geliştirilen ölçek ise, literatürde daha önceden yapılan çalışmalarda kullanılan ölçeklerden faydalanılarak geliştirilmiş geniş ve kapsayıcı yapıya sahip olup 5 boyut 20 maddeden oluşmaktadır. Kapsamı ve literatürdeki çalışmalar tarafından sıklıkla tercih edilmesi nedeniyle bu çalışmada da bu ölçek kullanılmıştır. Ölçekte yer alan ifadelerden dört tanesi ters kodludur. Anlaşıırlığı artırma adına ters kodlu ifadeler tekrar kodlanmıştır. Örgütsel inovasyonla ilgili ifadelerin oluşturduğu boyutlar aşağıda yer almaktadır:

- 1-4. Ifadeler : : Ürün İnovasyonu (Üi)

- 5-8. ifadeler : Pazar İnovasyonu (Pi)

- 9-12. Ifadeler : Süreç İnovasyonu (Si)

- 13-16. Iffadeler : Davranış İnovasyonu (Di)

- 17-20. Ifadeler : Stratejik İnovasyon (Si)

Örgütsel öğrenme değişkeni için ise literatürde öne çıkan üç ölçek vardır. Bunlardan ilki, Hult ve Ferrel (1997) tarafından geliştirilen 4 boyutlu 17 maddeli ölçektir. Ikincisi Goh ve Richard (1997) tarafından geliştirilen 4 boyutlu ve 20 maddeli ölçektir. Bir diğeri literatürde en çok atıf alan çalışmalardan olduğu için bu çalışmada da kullanılan Calantone vd. (2002) tarafından geliştirilen 17 ifade ve 4 boyuttan oluşan ölçektir. Bu ölçekteki ifadelerden bir tanesi ters kodlu olduğu için tekrar kodlanmıştır. Örgütsel öğrenme ilgili ifadelerin oluşturduğu boyutlar aşağıda yer almaktadır:

- 1-4. Ifadeler : Öğrenmeye Bağlılık (ÖB)

- 5-8. ifadeler : Paylaşılan Vizyon (PV)

- 9-12. Ifadeler : Açık Fikirlilik (AF)

- 13-17. İfadeler : Örgüt İçi Bilgi Paylaşımı (ÖBP) 


\subsection{Araştırma Evren ve Örneklemi}

Araştırmanın evrenini Konya ilinde gıda, inşaat, kâğıt/matbaa, mobilya ve plastik sektörlerinde faaliyet gösteren beş işletmenin tüm çalışanları oluşturmaktadır. Araştırma için ilgili işletmeler ile görüşülerek gerekli izinler alınmış, internet üzerinden tasarımı yapılan anketler çalışanlara e-posta yoluyla iletilmiştir. Anketler gönderildikten sonra katılımcılara farklı zaman dilimlerinde hatırlatma mesajı gönderilmiştir. Ayrıca işletmelerin insan kaynakları yöneticileri ile katılımı artırma hususunda telefonla görüşülmüştür. İlgili işletmelerin çalışan sayısı ve elde edilen anket sayıları Tablo 1'de verilmiştir. Araştırma evreninde 1516 çalışan bulunmaktadır. Araştırma 2019 Kasım-Aralık tarihlerinde yapılmıştır. Elde edilen anket sayısı araştırma evrenindeki toplam çalışan sayısının \%17,9'ini oluşturmaktadır.

Tablo 1: Anket Verileri

\begin{tabular}{|c|c|c|}
\hline Sektör ${ }^{4}$ & Çalışan Sayısı & Anket Sayısı \\
\hline Gıda & 412 & 22 \\
\hline İnşaat & 367 & 121 \\
\hline Kâğıt/Matbaa & 449 & 11 \\
\hline Mobilya & 88 & 27 \\
\hline Plastik & 200 & 91 \\
\hline Toplam & 1516 & 272 \\
\hline
\end{tabular}

Örnek kütle belirlenirken, Yazıcıoğlu ve Erdoğan (2004: 50) tarafından hazırlanan belirli evrenler için kabul edilebilir örneklem büyüklükleri tablosu referans alınmıştır. Tabloya $\pm 0,05$ örnekleme hatası; $p=0,08$ (ana kütledeki $X^{\prime}$ in gözlenme oranı) ve $q=0,02$ (ana kütledeki $X^{\prime}$ 'in gözlenmeme oranı) olmak kaydıyla belirlenen örnek kütle sayısı 224'tür. Bu bağlamda elde edilen 272 anketin ana kütleyi temsil etme gücünün olduğu söylenebilir.

\section{Bulgular}

Katılımcıların demografik bilgileri incelendiğinde araştırmaya katılanların büyük çoğunluğunu $(\% 94,5)$ erkekler oluşturmaktadır. Çalışanların yaşları dikkate alındığında ise en yüksek oran \%25,7 ile 40 yaş üzeri çalışanlar oluşturmaktadır. Ayrıca 30 yaş ve üstü çalışanların oranı \%67,7'dir. Ankete katılanların \%83,8'i alt kademe çalışanlardan oluşmakta ve en fazla anket verisi inşaat sektöründeki anketlerden oluşmaktadır. Ankete katılan çalışanların bulundukları işletmede çalışma sürelerine bakıldığında \%51,4'ünün çalışma sürelerinin 8 yıl ve üstü olduğu görülmektedir. Bir üst yöneticisi ile çalışma süresine bakıldığında ise bu sürenin 8 yıl ve daha fazla olduğu çalışanların oranı \%37,5'tir. Katılımcıların demografik bilgilerinin yanı sıra araştırmada kullanılan ölçeklere ait tanımlayıcı istatistikler de incelenmiştir. illgili ölçek ve boyutlarına ait tanımlayıcı istatistikler Tablo 2'te veriliştir.

Tablo 2 incelendiğinde, dönüşümcü liderlik ölçeği boyutlarından katılım oranı en yüksek olan entelektüel uyarım boyutu olup, bu boyuttaki maddelerden katılım derecesi en yüksek olan ise "Yöneticim sorunların çözümünde farklı bakış açıları arar. $(3,77)$ " maddesidir. Bu ölçekteki maddelere katılım oranı en düşük olan boyut ise bireysel ilgi boyutudur. Bu

\footnotetext{
${ }^{4}$ Örgütsel Öğrenme, Dönüşümcü Liderlik ve Örgütsel İnovasyon ölçekleri için farklı sektörlerden gelen veriler arasında bir farklılık olup olmadı̆̆ını test etmek için Kruskal-Wallis testi yapılmıştır. Yapılan test sonuçlarına göre Örgütsel Öğrenme ölçeği için $x^{2}=4,592$ ve $p=0,332$; Dönüşümcü Liderlik ölçeği için $x^{2}=6,493$ ve $p=0,165$; Örgütsel İnovasyon ölçeği için $x^{2}=4,198$ ve $p=0,380$ olup gruplar arasında istatistiksel bakımdan anlamlı bir farklılığın olmadığını göstermektedir. Bu bağlamda beş farklı gruptan gelen veriler tek bir gruptan gelen veri olarak değerlendirilmiştir.
} 
boyuttaki maddelerden katılım derecesi en düşük olan ise "Yöneticim öğretmeye ve yetiştirmeye zaman harcar. $(3,52)$ "' maddesidir.

Örgütsel inovasyon ölçeği boyutlarından katılım oranı en yüksek olan süreç inovasyonu boyutu olup, bu boyuttaki maddelerden katılım derecesi en yüksek olan ise "işletmemiz son beş yıl içerisinde birçok yeni yönetim yaklaşımı geliştirmiştir $(3,68)$ " maddesidir. Örgütsel inovasyon ölçeğinde katılım oranı en düşük olan boyut ürün inovasyonu boyutudur. Bu boyuttaki maddelerden katılım derecesi en düşük olan ise "Rakiplerimize kıyasla yeni ürün ve hizmet sunumunda daha başarılııı. $(3,19)$ " maddesidir.

Tablo 2: Ölçeklere Ait Tanımlayıcı Istatistikler

\begin{tabular}{|c|c|c|c|c|c|}
\hline Değişkenler ve Alt Boyutları & & $N$ & Ort. & Std. Sapma & Cronbach Alpha \\
\hline Dönüşümcü Liderlik & DL & 272 & 3,64 & 1,05 & 0,985 \\
\hline Ideal Etki-Atfedilen & IEA (4 madde) & 272 & 3,61 & 1,16 & \\
\hline ideal Etki-Davranış & IED (4 madde) & 272 & 3,63 & 1,12 & \\
\hline IIlham Verici Motivasyon & iM (4 madde) & 272 & 3,70 & 1,08 & \\
\hline Entelektüel Uyarım & EU (4 madde) & 272 & 3,73 & 1,13 & \\
\hline Bireysel İlgi & $\mathrm{Bi}(4$ madde) & 272 & 3,55 & 1,17 & \\
\hline Örgütsel İnovasyon & öi & 272 & 3,38 & 0,99 & 0,980 \\
\hline Ürün Inovasyonu & $\ddot{U i}$ (4 madde) & 272 & 3,28 & 1,13 & \\
\hline Pazar İnovasyonu & Pi (4 madde) & 272 & 3,35 & 1,11 & \\
\hline Süreç İnovasyonu & si (4 madde) & 272 & 3,63 & 1,02 & \\
\hline Davranış İnovasyonu & Di (4 madde) & 272 & 3,32 & 1,04 & \\
\hline Stratejik Inovasyon & STi (4 madde) & 272 & 3,35 & 1,14 & \\
\hline Örgütsel Öğrenme & Öö & 272 & 3,48 & 1,04 & 0,981 \\
\hline Öğrenmeye Bağlılık & ÖB (4 madde) & 272 & 3,52 & 1,11 & \\
\hline Paylaşılan Vizyon & PV (4 madde) & 272 & 3,58 & 1,11 & \\
\hline Açık Fikirlilik & $A F(4$ madde) & 272 & 3,40 & 1,14 & \\
\hline Örgüt içi Bilgi Paylaşımı & $O ̈ B P(5$ madde $)$ & 272 & 3,42 & 1,12 & \\
\hline
\end{tabular}

Notlar: (i) $n=272$, (ii) ölçekte 1 kesinlikle katılmıyorum ve 5 kesinlikle katılıyorum anlamındadır.

Örgütsel öğrenme ölçeği boyutlarından katılım oranı en yüksek olan paylaşılan vizyon boyutu olup, bu boyuttaki maddelerden katılım derecesi en yüksek olan ise "Kurumsal sistemimizin bütün aşama, fonksiyon ve bölümü ile ilgili görüşümüzde tam bir fikir birliği vardır. $(3,67)$ " maddesidir. Bu ölçekteki maddelere katılım oranı en düşük olan boyut ise açık fikirlilik boyutudur. Bu boyuttaki maddelerden katılım derecesi en düşük olan ise "Müşterilerimiz hakkında eleştirel olarak yaptığımız varsayımları dışarıya yansıtmaktan çekinmeyiz. $(3,35)$ " maddesidir.

Bu araştırmanın temel amacı değişkenler arası ilişkilerin incelenerek, dönüşümcü liderlik ile örgütsel inovasyon arasındaki ilişkide örgütsel öğrenmenin aracılık etkisinin olup olmadığının incelenmesidir. Bu bağlamda değişkenler arası ilişkilerin yönü ve şiddetinin belirlenebilmesi için dönüşümcü liderlik, örgütsel inovasyon ve örgütsel öğrenme ölçekleri arasındaki ilişki spearman korelasyonu katsayısı kullanılarak hesaplanmıştır. Elde edilen bulgular Tablo 3'te sunulmuştur. 
Tablo 3: Değişkenler Arası Korelâsyon Analizi Sonuçları

\begin{tabular}{|c|c|c|c|}
\hline Değişkenler & Dönüşümcü Liderlik & Örgütsel İnovasyon & Örgütsel Öğrenme \\
\hline Dönüşümcü Liderlik & - & & \\
\hline Örgütsel İnovasyon & $0,803^{*}$ & - & \\
\hline Örgütsel Öğrenme & $0,849^{*}$ & $0,835^{*}$ & - \\
\hline
\end{tabular}

$* p<0,01$

Tablo 3'teki korelasyon matrisinde görüldüğü üzere dönüşümcü liderlik ile örgütsel inovasyon arasında pozitif yönlü, istatistiki açıdan anlamlı ve güçlü bir ilişkinin olduğu görülmektedir. Bu sonuçlar literatürde, Jung vd. (2003: 536), Gumusluoglu ve Ilsev (2009: 469) ve Jaiswal ve Dhar (2015: 39) tarafından yapılan çalışmalardaki sonuçlar ile benzerlik göstermektedir. Dönüşümcü liderlik ile bir diğer değişken örgütsel öğrenme arasındaki ilişki incelendiğinde, pozitif yönlü, istatistiki açıdan anlamlı ve güçlü bir ilişkinin olduğu görülmektedir. Bu sonuçlar literatürde eğitim faaliyetleri ve üretim işletmeleri gibi farklı alanlarda, dönüşümcü liderlik ile örgütsel öğrenme değişkenlerine ilişkin yapılan çalışmaların (Hsiao ve Chang, 2011: 621; Hasiao ve Chang, 2011: 621; García vd., 2012: 1040; Abbasi ve Zamani, 2013: 505) sonuçları ile benzerlik göstermektedir.

Tablo 3'teki bir diğer değişkenler arası ilişki incelendiğinde, örgütsel inovasyon ile örgütsel öğrenme arasında da pozitif yönlü, istatistiki açıdan anlamlı ve güçlü bir ilişkinin olduğu görülmektedir. Bu sonuçlarda literatürde farklı alanlarda bu iki değişkene yönelik yapılan çalışmaların (Liao vd., 2008: 19; Jiménez ve Sanz, 2011: 408; Liao ve Wu, 2010: 1099; Eshlaghy ve Maatofi 2011: 114; Onağ ve Tepeci 2016: 50) sonuçları ile benzerlik göstermektedir.

Değişkenler arası ilişkilerin tespit edilmesinden sonra bu nedensel ilişkilerin irdelenmesi, araştırma hipotezlerini test edilmesi ve örgütsel öğrenmenin aracllık etkisinin değerlendirilmesi amacıyla araştırmanın kavramsal modeline uygun olarak, Hayes (2013) tarafından önerilen sistematikten yararlanılmış ve aşağıdaki model önerilmiştir.

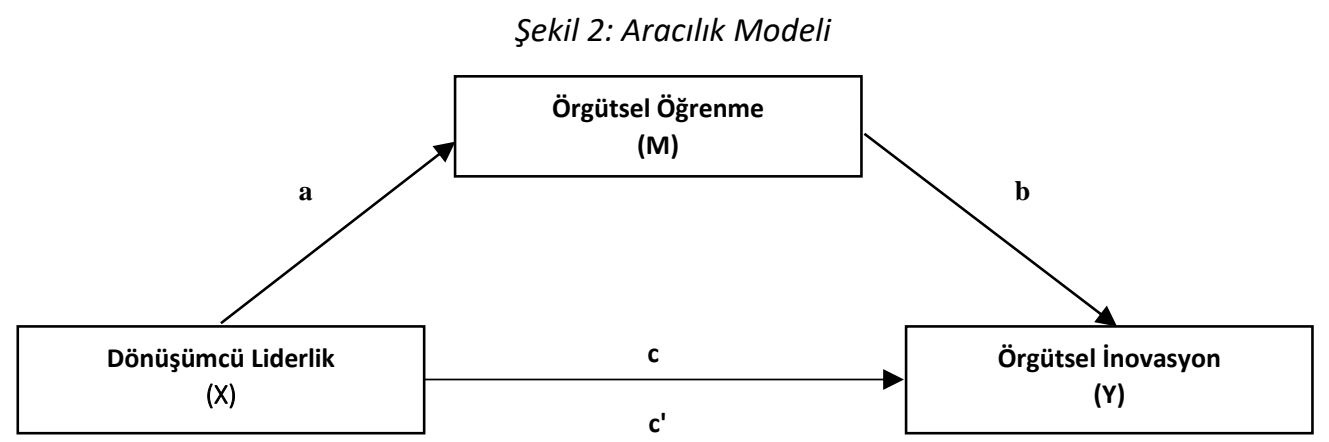

Kaynak: Hayes (2013)'den uyarlanmıştır.

Hayes (2013)'ten uyarlanan modele göre; dönüşümcü liderliğin ve örgütsel öğrenmenin, örgütsel inovasyonu etkilediği varsayılmaktadır. Ayrıca dönüşümcü liderliğin örgütsel inovasyon üzerindeki etkisinde örgütsel öğrenmenin aracı role sahip olduğu varsayılmaktadır. Şekil 2'de gösterilen ve Hayes (2013) tarafından geliştirilen sistematiğe uygun olarak, 4 numaralı aracılık ilişki modeli, Process Makro eklentili SPSS 22 programı ile analiz edilmiştir. Sonuçlar aşağıda adım adım ifade edilmiştir. 
Tablo 4: Dönüşümcü Liderlik 'in (X) Örgütsel Inovasyon (Y) Üzerindeki Etkisi

\begin{tabular}{|c|c|c|c|c|c|c|}
\hline Bağımlı Değişken & $\Delta \mathbf{R}^{2}$ & Bağımsız Değişkenler & b & Std. Hata & $\mathbf{t}$ & $\mathbf{F}$ \\
\hline \multirow{2}{*}{ Örgütsel İnovasyon } & \multirow{2}{*}{0,674} & Sabit & 0,554 & 0,124 & $4,443^{*}$ & \multirow{2}{*}{559,506} \\
\hline & & Dönüşümcü Liderlik & 0,777 & 0,032 & $23,654^{*}$ & \\
\hline
\end{tabular}

Notlar: (i)*p<0,001. (ii) Standardize edilmiş beta katsayıları (b) raporlanmıştır. (iii) Dönüşümcü Liderlik için \%95 Cl $[0,712-0,841]$.

Tablo 4, bağımsız değişken dönüşümcü liderliğin, örgütsel inovasyon üzerindeki etkisini gösteren regresyon analizi sonuçlarını göstermektedir. Aracı değişkenin olmadığı bu durumda analiz sonuçları, dönüşümcü liderliğin örgütsel inovasyon üzerindeki etkisinin istatistiksel olarak anlamlı olduğunu ve pozitif yönde etkilediğini göstermektedir ( $b=0,821 ; \% 95 \mathrm{Cl}^{5}[0,712$ $0,841] ; t=23,654$ ve $p<0,001$ ). Regresyon analizi sonuçlarına göre $R^{2}$ (açıklanan varyansın yüzdesi) ve $F$ (regresyon modelinin anlamlılık derecesi) değerleri örgütsel inovasyonun dönüşümcü liderlik ile açıklanabileceğini göstermektedir. Modelde c yolu ile tanımlanan bu etki, önerilen $\mathrm{H}_{1}$ hipotezini (Dönüşümcü liderliğin, örgütsel inovasyon üzerinde pozitif yönlü bir etkisi vardır.) desteklemektedir. Korelasyon ve regresyon analizi sonuçları bağlamında, bu örneklem için dönüşümcü liderlik özelliği, işletmenin örgütsel inovasyon özelliğine olumlu yönde katkı sağlamaktadır. İşletmelerin inovasyon faaliyetlerinin artmasında dönüşümcü liderliğin olumlu etkisi, literatürde liderlik ve farklı boyutları ile inovasyon arasındaki ilişkiye yönelik yapılan çalışmalarda da benzer sonuçlar elde edilerek vurgulanmıştır (Jung vd., 2003: 525; Gumusluoglu ve Ilsev, 2009: 517; Jaiswal ve Dhar, 2015: 30; Yıldırım vd. 2018: 213).

Tablo 5: Dönüşümcü Liderlik' in (X) Örgütsel Öğrenme (M) Üzerindeki Etkisi

\begin{tabular}{|c|c|c|c|c|c|c|}
\hline Bağımlı Değişken & $\Delta \mathbf{R}^{2}$ & Bağımsız Değişkenler & b & Std. Hata & $\mathbf{t}$ & $\mathbf{F}$ \\
\hline \multirow{2}{*}{ Örgütsel Öğrenme } & \multirow{2}{*}{0,766} & Sabit & 0,315 & 0,111 & $2,853^{*}$ & \multirow{2}{*}{$885,397^{*}$} \\
\hline & & Dönüşümcü Liderlik & 0,867 & 0,030 & $29,756^{*}$ & \\
\hline
\end{tabular}

Notlar: (i)*p<0,001. (ii) Standardize edilmiş beta katsayıları (b) raporlanmıştır. (iii) Dönüşümcü Liderlik için \%95 Cl [0,810-0,952].

Tablo 5, bağımsız değişken dönüşümcü liderliğin, örgütsel öğrenme üzerindeki etkisini gösteren regresyon analizi sonuçlarını göstermektedir. Analiz sonuçları, dönüşümcü liderliğin örgütsel öğrenme üzerindeki etkisinin istatistiksel olarak anlamlı olduğunu ve pozitif yönde etkilediğini göstermektedir ( $b=0,875 ; \% 95 \mathrm{Cl}[0,810-0,952] ; t=29,756$ ve $p<0,001)$. Regresyon analizi sonuçlarına göre $R^{2}$ (açıklanan varyansın yüzdesi) ve $F$ (regresyon modelinin anlamlılık derecesi) değerleri örgütsel öğrenmenin dönüşümcü liderlik ile açıklanabileceğini göstermektedir. Modelde a yolu ile tanımlanan bu etki, önerilen $\mathrm{H}_{2}$ hipotezini (Dönüşümcü liderliğin, örgütsel öğrenme üzerinde pozitif yönlü bir etkisi vardır.) desteklemektedir. Korelasyon ve regresyon analizi sonuçları bu örneklem için, dönüşümcü liderliğin organizasyonların öğrenme kabiliyetine olumlu yönde katkı sağladığını göstermektedir. Dönüşümcü liderliğin örgütsel öğrenme üzerine etkisini konu alan birçok çalışmada da benzer sonuçlar ortaya konulmuştur (Hsiao ve Chang, 2011: 621; García vd., 2012: 1040; Abbasi ve Zamani, 2013: 505).

5 \%95 Confidence Interval: Güven Aralığı (Parantez içindeki değerler sıfır değerini kapsamadığından sonuçlar anlamlıdır (Lee, 2016:559; Greenland vd., 2016:343.)) 
Tablo 6: Dönüşümcü Liderlik' in (X) ve Örgütsel Öğrenmenin (M) Örgütsel Inovasyon (Y) Üzerindeki Etkisi

\begin{tabular}{|c|c|c|c|c|c|c|}
\hline Bağımlı Değişken & $\Delta \mathbf{R}^{2}$ & Bağımsız Değişkenler & b & Std. Hata & $\mathbf{t}$ & $\mathbf{F}$ \\
\hline \multirow{3}{*}{ Örgütsel İnovasyon } & \multirow{3}{*}{0,757} & Sabit & 0,375 & 0,109 & $3,423^{*}$ & \multirow{3}{*}{$418,510^{*}$} \\
\hline & & Dönüşümcü Liderlik & 0,286 & 0,059 & $4,853^{* * *}$ & \\
\hline & & Örgütsel Öğrenme & 0,566 & 0,059 & $9,540^{*}$ & \\
\hline
\end{tabular}

Notlar: (i)*p<0,001, **p<0,05, ***p<0,01. (ii) Standardize edilmiş beta katsayıları (b) raporlanmıştır. (iii) Dönüşümcü Liderlik için \%95 Cl [0,170-0,401]; Örgütsel Öğrenme için \%95 Cl [0,450-0,683].

Tablo 6'da ise dönüşümcü liderlik ile aracı değişken örgütsel öğrenmenin birlikte örgütsel inovasyonu üzerindeki etkisini gösteren analiz sonuçları yer almaktadır. Analiz sonuçları, dönüşümcü liderliğin örgütsel inovasyonu anlamlı ve olumlu yönde etkilediğini göstermektedir $(b=0,301 ; \% 95 \mathrm{Cl}[0,170-0,401] ; t=4,853$ ve $p<0,001)$. Örgütsel öğrenme de örgütsel inovasyonu anlamlı düzeyde ve olumlu yönde etkilemektedir $(b=0,593 ; \% 95 \mathrm{Cl}$ $[0,450-0,683] ; t=9,540$ ve $p<0,001$ ). Regresyon analizi sonuçlarına göre $R^{2}$ (açıklanan varyansın yüzdesi) ve $F$ (regresyon modelinin anlamlılık derecesi) değerleri örgütsel inovasyonun örgütsel öğrenme ile açılanabileceğini göstermektedir. Korelasyon ve regresyon analizi sonuçları bu örneklem için, örgütsel öğrenmenin organizasyonların inovasyon faaliyetlerine olumlu yönde katkı sağladığını göstermektedir. Bu sonuçlar bağlamında, modelde b yolu ile ifade edilen $\mathrm{H}_{3}$ hipotezi (Örgütsel öğrenmenin örgütsel inovasyon üzerinde pozitif yönlü bir etkisi vardır.) desteklenmekte ve literatürde de birçok çalışmadaki sonuçlara benzer bir sonuca ulaşılmaktadır (Liao vd., 2008: 19; Liao ve Wu, 2010: 1099; Jiménez ve Sanz, 2011: 408; Eshlaghy ve Maatofi 2011: 114 Onağ ve Tepeci, 2016: 50).

Tablo 7: Dönüşümcü Liderlik' in (X) Örgütsel Inovasyon (Y) Üzerindeki Toplam, Doğrudan ve Dolaylı Etkileri

\begin{tabular}{|c|c|c|c|c|c|c|}
\hline & Etki & Std. Hata & $\mathbf{t}$ & $\mathbf{p}$ & LLCl & $\mathrm{ULCl}$ \\
\hline$X^{\prime}$ in Y üzerindeki toplam etkisi (c yolu) & 0,777 & 0,033 & 23,635 & $<0,001$ & 0,712 & 0,841 \\
\hline$X^{\prime}$ in Y üzerindeki doğrudan etkisi (c' yolu) & 0,285 & 0,059 & 4,852 & $<0,001$ & 0,169 & 0,401 \\
\hline X'in Y üzerindeki dolaylı etkisi & 0,491 & & & & 0,360 & 0,636 \\
\hline$X^{\prime}$ in Y üzerindeki kısmi standardize etkisi & 0,493 & & & & 0,367 & 0,637 \\
\hline$X^{\prime}$ in Y üzerindeki tam standardize etkisi & 0,519 & & & & 0,382 & 0,670 \\
\hline
\end{tabular}

Dönüşümcü liderliğin aracı değişken örgütsel öğrenme ile örgütsel inovasyon üzerindeki doğrudan ve dolaylı etkilerinin gösterildiği Tablo 7'deki sonuçlara göre; dönüşümcü liderliğin doğrudan anlamlı bir etkisinin olduğu görülmektedir $(b=0,285 ; t=4,850 ;$ ve $p<0,001)$. Tabloda dolaylı etki olarak ifade edilen değerler, dönüşümcü liderliğin $(X)$, örgütsel öğrenme aracı değişken vasıtasıyla örgütsel inovasyon üzerinde istatistiki açıdan anlamlı ve olumlu yönde bir etkisi olduğunu göstermektedir ( $b=0,491$ ve $\% 95 \mathrm{Cl}[0,360-0,636])$. Bu iki sonuç dikkate alındığında dönüşümcü liderlik $(X)$ ve örgütsel öğrenmenin $(M)$, örgütsel inovasyon üzerinde anlamlı ve olumlu bir etkiye sahip olduğu $(b=0,777 ; t=23,654 ;$ ve $p<0,001)$, bundan dolayı örgütsel öğrenmenin aracılık rolü olduğu söylenebilir. Bu sonuçlara göre $\mathrm{H}_{4}$ hipotezi (Dönüşümcü liderliğin örgütsel inovasyon üzerindeki etkisinde örgütsel öğrenmenin aracı rolü vardır.) desteklenmektedir.

Tablo 7'deki sonuçlar, dönüşümcü liderliğin doğrudan ve dolaylı olarak örgütsel inovasyona katkı sağladığını ortaya koymaktadır. Örgütsel öğrenme gibi değişkenler, yöneticilerin örgütsel inovasyona olan etkilerinde aracılık yapan değişkenlerdir. Dönüşümcü liderliğin örgütsel inovasyon üzerindeki dolaylı etkisi, doğrudan olan etkisinden daha 
büyüktür. Bu da dönüşümcü liderliğin aracı değiş̧en örgütsel öğrenme vasıtasıyla daha fazla örgütsel inovasyona yol açtığını göstermektedir. Örgütsel inovasyon, örgütsel öğrenmedeki önemli değişikliklerden kaynaklanır. Bu sonuçlar bağlamında örgüt üyelerinin dönüşümcü liderlik özelliklerinin yanında örgütsel öğrenmeyi de desteklemeleri örgütsel inovasyonu ortaya çıkartacağı görülmektedir.

\section{Sonuç}

İçinde bulunduğumuz yüzyılda, sürekli değişen ve gelişen dinamik çevre koşulları, işletmelerdeki yönetimden sorumlu kişileri daha etkili bir yönetim arayışına itmektedir. Sürdürülebilir bir rekabet avantajı yakalamak için, pazardaki değişim ve dönüşümü yakalamak gerekmektedir. Bu da işletmelerin, çalışanlarının bilgi, beceri ve yaratıcı çabalarından yararlanarak sürekli yenilik yapmasını ve sahip oldukları kaynakların verimliliğini en üst düzeye çıkararak elde edilecekleri faydanın artırılmasını gerektirecektir. Bu bağlamda, bu dönüşümü gerçekleştirecek, çalışanları motive edecek, organizasyonel bir öğrenme ile yeniliğin önünü açacak dönüşümcü liderlere ihtiyaç vardır. Dönüşümcü liderler mevcut durumun dinamiklerini tespit ederek işletmeler için yeni stratejiler belirleyebilirler. Bu sayede organizasyonlar değişen ve gelişen çevre koşullarına ayak uydurabilir hatta değişimin kendisi olabilirler. Dönüşümcü liderliğin inovasyon üzerindeki etkisi örgütsel öğrenme gibi aracı faktörler ile de artmaktadır. Yüksek derecede gerçekleşen organizasyonel anlamdaki öğrenme daha iyi organizasyonel inovasyonu tetikleyecektir.

Bu çalışmada, dönüşümcü liderlik ile örgütsel inovasyon arasındaki ilişki ve bu ilişki üzerinde örgütsel öğrenmenin aracı rolü irdelenmiştir. Yapılan korelâsyon ve regresyon analizleri sonucunda dönüşümcü liderlik ile örgütsel inovasyon arasında pozitif yönlü ve anlamlı bir ilişki tespit edilmiştir. Bu sonuç örgütsel inovasyonun dönüşümcü liderlik ile açıklanabileceğini göstermektedir. Araştırmanın yapıldığı örneklem için dönüşümcü liderlik özelliği, işletmenin örgütsel inovasyon özelliğine olumlu yönde katkı sağlamaktadır. Dönüşümcü liderlik ile örgütsel öğrenme arasındaki ilişkileri incelemeye yönelik yapılan analiz sonucunda da dönüşümcü liderliğin örgütsel öğrenme üzerinde pozitif yönlü ve anlamlı bir etkisi olduğu tespit edilmiştir. Bu sonuç dönüşümcü liderlik özelliklerinin organizasyonların öğrenme kabiliyetine olumlu yönde katkı sağladığını göstermektedir.

Araştırmada elde edilen sonuçlardan bir diğeri ise örgütsel öğrenme ile örgütsel inovasyon arasındaki ilişkidir. Sonuçlar örgütsel öğrenme faaliyetlerinin örgütsel inovasyon üzerinde pozitif yönlü ve anlamlı bir etkisinin olduğunu göstermiştir. Bu sonuç, araştırmanın yapıldığı örneklem için örgütsel öğrenmenin organizasyonların inovasyon faaliyetlerine olumlu yönde katkı sağladığını göstermektedir. Dönüşümcü liderlik, örgütsel öğrenme ve örgütsel inovasyon değişkenleri arasında tespit edilen bu ilişkilerin yanında, dönüşümcü liderlik ile örgütsel inovasyon arasındaki ilişkide örgütsel öğrenmenin aracı rolü de analiz edilmiştir. Elde edilen sonuçlar dönüşümcü liderliğin doğrudan ve dolaylı olarak örgütsel inovasyona katkı sağladığını ortaya koymaktadır. Dönüşümcü liderliğin örgütsel inovasyon üzerindeki dolaylı etkisi, doğrudan olan etkisinden daha büyüktür. Bu da dönüşümcü liderliğin aracı değişken örgütsel öğrenme vasıtasıyla daha fazla örgütsel inovasyona yol açtığını göstermektedir. Bu sonuçlar bağlamında örgüt üyelerinin dönüşümcü liderlik özelliklerinin yanında örgütsel öğrenmeyi de desteklemeleri örgütsel inovasyonu ortaya çıkartacaktır. Değişkenler arasındaki bu bütüncül ilişkiler dikkate alındığında, işletmelerin bulundukları rekabetçi çevre koşullarında sürdürülebilir bir rekabet gücü yakalayabilmesi için, dönüşümcü liderler vasıtasıyla örgütsel öğrenmeyi bir örgüt kültürü haline getirerek, bireysel ve örgütsel olarak yeniliğe ve dönüşüme 
odaklanması gerektiği aşikardır. Bu öğrenme kültürünün oluşması ve işletmeye yerleşmesi için dönüşümcü liderlik özelliğine sahip yöneticilerin rolü büyüktür. İşletmelerin bu zorlu koşullarda amaçlarına ulaşabilmesi için, işletmeyi dar bir çerçeveden çıkarıp yeni hedefler ve stratejiler belirleyebilen, iç ve dış çevresel dönüşümü kurgulayacak ve sürdürecek liderlere sahip olmaları gerekecektir.

İşletmelerin rekabet avantajı sağlayabilmeleri açısından inovasyon önemli bir faktördür. Bu çalışmada inovasyon üzerinde, dönüşümcü liderliğin ve örgütsel öğrenmenin etkisi araştırılmış olsa da inovasyon üzerinde sadece bu faktörlerin etkisi olduğu söylenemez. Bunun yanında birçok faktör inovasyon üzerinde etkili olmaktadır. Ayrıca araştırmanın yapıldığı örneklem de önemli bir kısıttır. İnovasyon kavramı üzerinde etkisi olan unsurların belirlenmesine yönelik daha detaylı çalışmalar yapılarak, örneklem sektörel ya da bölgesel anlamda genişletilerek bu ve literatürdeki diğer çalışmaların sonuçları ile karşılaştırma yapılmasının literatür araştırmalarına önemli katkılar sunacağı düşünülmektedir. 


\section{Kaynakça}

Abbasi, E.; Zamani-Miandashti, N. (2013). "The Role of Transformational Leadership, Organizational Culture and Organizational Learning in Improving the Performance of Iranian Agricultural Faculties", Higher Education, Vol. 66 No. 4: 505-519.

Aga, D. A.; Noorderhaven, N.; Vallejo, B. (2016). "Transformational leadership and project success: The mediating role of team building". International Journal of Project Management, Vol. 34 No. 5: 806-818.

Alegre, J.; Chiva, R. (2008). "Assessing the Impact of Organizational Learning Capability on Product Innovation Performance: An Empirical Test." Technovation, Vol. 28 No. 6: 315-326.

Ali, A.; Krapfel Jr. R.; LaBahn, D. (1995). "Product Innovativeness and Entry Strategy: Impact on Cycle Time and Break-Even Time." Journal of Product Innovation Management, Vol. 12 No. 1: 54-69.

Altunışık, R.; Coşkun, R.; Bayraktaroğlu, S.; Yildirim, E. (2017). Sosyal Bilimlerde Araştirma Yöntemleri. Sakarya: Sakarya Yayıncılık.

Amabile, T. M.; Conti, R.; Coon, H.; Lazenby, J.; Herron, M. (1996). “Assessing the Work Environment for Creativity." Academy of Management Journal, Vol. 39 No. 5: 1154-1184.

Anzola-Román, P.; Bayona-Sáez, C.; García-Marco, T. (2018). “Organizational Innovation, Internal R\&D and Externally Sourced Innovation Practices: Effects on Technological Innovation Outcomes." Journal of Business Research, Vol. 91 No: 233-247.

Attar, M. (2014). “Üst Düzey Yöneticilerin Liderlik Özelliklerinin Örgütsel Ustalık Düzeyine Etkisi: Türk Bankacılık Sektörü Üzerine Bir Araştırma. (Doktora Tezi)”. Selçuk Üniversitesi Sosyal Bilimler Enstitüsü, Konya.

Avcı, N.; Küçükusta, D. (2009). "Konaklama İşletmelerinde Örgütsel Öğrenme, Örgütsel Bağlılık ve İşten Ayrılma Eğilimi Arasındaki iliş̧ki." Anatolia Turizm Araştırmaları Dergisi, C. 20 S. 1: 33-44.

Avolio, B. J.; Bass, B. M.; Jung, D. I. (1999). "Re-Examining the Components of Transformational and Transactional Leadership Using the Multifactor Leadership." Journal of Occupational and Organizational Psychology, Vol. 72 No. 4 : 441-462.

Azar, G.; Ciabuschi, F. (2017). “Organizational Innovation, Technological Innovation, And Export Performance: The Effects of Innovation Radicalness and Extensiveness." International Business Review, Vol. 26 No. 2: 324-336.

Bass, B. M.; Avolio, B. J. (1993). "Transformational Leadership and Organizational Culture." Public Administration Quarterly, Vol. 17 No. 1: 112-121.

Bass, B. M.: Bass Bernard, M. (1985). "Leadership and Performance Beyond Expectations."

Bass, B. M.: Riggio, R. E. (2006). Transformational Leadership. New Jersey: Mahwah.

Boamah, S. A.; Laschinger, H. K. S.; Wong, C.; Clarke, S. (2018). "Effect of Transformational Leadership on Job Satisfaction and Patient Safety Outcomes." Nursing Outlook, Vol. 66 No. 2: 180-189.

Calantone, R. J.; Cavusgil, S. T.; Zhao, Y. (2002). "Learning Orientation, Firm Innovation Capability, And Firm Performance." Industrial Marketing Management, Vol. 31 No. 6: 515-524.

Damanpour, F. (1996). "Organizational Complexity and Innovation: Developing and Testing Multiple Contingency Models." Management Science, Vol. 42 No. 5: 693-716.

Damanpour, F.; Aravind, D. (2011). "Managerial Innovation: Conceptions, Processes, And Antecedents." Management and Organization Review, Vol. 8 No: 423-454.

Damanpour, F.; Evan, W. M., (1984). "Organizational Innovation and Performance: The Problem of 'Organizational Lag'." Administrative Science Quarterly, Vol. 29 No. 3: 392-409.

Demirel, Y.; Tohum, E. U. (2018). "Örgütsel Öğrenmenin Örgütsel Vatandaşlık Davranışı Üzerine Etkisi." MANAS Sosyal Araştırmalar Dergisi, C. 7 S. 2: 277-295.

Dionne Shelley, D. (2004). "Transformational Leadership and Team Performance." Journal of Organizational Change Management, Vol. 17 No. 2: 177-193.

Dong, Y.; Bartol, K. M.; Zhang, Z. X.; Li, C. (2017). "Enhancing Employee Creativity Via Individual Skill Development and Team Knowledge Sharing: Influences of Dual-Focused Transformational Leadership." Journal of Organizational Behavior, Vol. 38 No. 3: 439-458.

Elkins, T.; Keller, R. T. (2003). "Leadership in Research and Development Organizations: A Literature Review and Conceptual Framework." The Leadership Quarterly, Vol. 14 No. 4: 587-606.

Ellonen, R. (2008). "The Role of Trust in Organizational Innovativeness." European Journal of Innovation Management, Vol. 11 No. 2: 160-181. 


\section{Eskişehir Osmangazi Üniversitesi İktisadi ve İdari Bilimler Fakültesi Dergisi}

Eshlaghy, A. T.; Maatofi, A. (2011). "Learning Orientation, Innovation and Performance: Evidence from SmallSized Business Firms in Iran." European Journal of Social Sciences, Vol. 19 No. 1: 114-122.

Fay, D.; Shipton, H.; West, M. A.; Patterson, M. (2015). "Teamwork and Organizational Innovation: The Moderating Role of The HRM Context." Creativity and Innovation Management, Vol. 24 No. 2: 261-277.

Fiol, C. M.; Lyles, M. A. (1985). "Organizational Learning." Academy of Management Review, Vol. 10 No. 4: 803813.

García-Morales, V. J.; Jiménez-Barrionuevo, M. M.; Gutiérrez-Gutiérrez, L. (2012). "Transformational Leadership Influence on Organizational Performance Through Organizational Learning and Innovation." Journal of Business Research, Vol. 65 No. 7: 1040-1050.

Goh, S.; Richards, G. (1997). "Benchmarking the Learning Capability of Organizations." European Management Journal, Vol. 15 No. 5: 575-583.

Greenland, S.; Senn, S. J.; Rothman, K. J.; Carlin, J. B.; Poole, C.; Goodman, S. N.; Altman, D. G. (2016). "Statistical Tests, P Values, Confidence Intervals, And Power: A Guide to Misinterpretations." European Journal of Epidemiology, Vol. 31 No. 4: 337-350.

Gumusluoglu, L.; Ilsev, A. (2009). "Transformational Leadership, Creativity, And Organizational Innovation." Journal of Business Research, Vol. 62 No. 4: 461-473.

Hayes, A. F. (2013). Introduction to Mediation, Moderation, And Conditional Process Analysis. New York: The Guilford Press.

Hetland, J.; Hetland, H.; Bakker, A. B.; Demerouti, E. (2018). "Daily Transformational Leadership and Employee Job Crafting: The Role of Promotion Focus." European Management Journal, Vol. 36 No. 6: 746-756.

Hsiao, H.-C.; Chang, J.-C. (2011). "The Role of Organizational Learning in Transformational Leadership and Organizational Innovation." Asia Pacific Education Review, Vol. 12 No. 4: 621.

Huber, G. P. (1991). “Organizational Learning: The Contributing Processes and The Literature." Organization Science, Vol. 2 No. 1: 88-115.

Hult, G. T. M.; Ferrell, O. C. (1997). "Global Organizational Learning Capacity in Purchasing: Construct and Measurement." Journal of Business Research, Vol. 40 No. 2: 97-111.

Hurley, R. F.; Hult, G. T. M. (1998). "Innovation, Market Orientation, And Organizational Learning: An Integration and Empirical Examination." Journal of Marketing, Vol. 62 No. 3: 42-54.

Jaiswal, N. K.; Dhar, R. L. (2015). "Transformational leadership, innovation climate, creative self-efficacy, and employee creativity: A multilevel study". International Journal of Hospitality Management, Vol. 51 No. :30-41.

Jerez-Gomez, P.; Cespedes-Lorente, J.; Valle-Cabrera, R. (2005). “Organizational Learning Capability: A Proposal of Measurement." Journal of Business Research, Vol. 58 No. 6: 715-725.

Jiménez-Jiménez, D.; Sanz-Valle, R. (2011). "Innovation, Organizational Learning, And Performance." Journal of Business Research, Vol. 64 No. 4: 408-417.

Jung, D. I.; Chow, C.; Wu, A. (2003). "The Role of Transformational Leadership in Enhancing Organizational Innovation: Hypotheses and Some Preliminary Findings." The Leadership Quarterly, Vol. 14 No. 4: 525-544.

Kark, R.; Shamir, B.; Chen, G. (2003). "The Two Faces of Transformational Leadership: Empowerment and Dependency." Journal of Applied Psychology, Vol. 88 No. 2: 246-255.

Lashari, R. H.; Nazir, S. H.; Rana, A. H. (2020). "Impact of Organizational Learning and Transformational Leadership on Knowledge Sharing: An Empirical Study on Banking Sector of Pakistan." AJSS, Vol. 4 No. 3: 685-699.

Lee, D. K. (2016). "Alternatives to P Value: Confidence Interval and Effect Size." Korean Journal of Anesthesiology, Vol. 69 No. 6: 555-562.

Lei, H.; Leaungkhamma, L.; Le, P. B. (2020). "How Transformational Leadership Facilitates Innovation Capability: The Mediating Role of Employees' Psychological Capital." Leadership \& Organization Development Journal, Vol. 41 No. 4: 481-499.

Liao, S. H.; Wu, C. C. (2010). "System Perspective of Knowledge Management, Organizational Learning, And Organizational Innovation." Expert Systems with Applications, Vol. 37 No. 2: 1096-1103.

Liao, S.-H.; Fei, W.-C.; Liu, C.-T. (2008). "Relationships Between Knowledge Inertia, Organizational Learning and Organization Innovation." Technovation, Vol. 28 No. 4: 183-195.

Liao, S.-h.; Wu, C.-c.; Hu, D.-c.; Tsui, K.-a. (2010). "Relationships Between Knowledge Acquisition, Absorptive Capacity, And Innovation Capability: An Empirical Study on Taiwan's Financial and Manufacturing Industries." Journal of Information Science, Vol. 36 No. 1: 19-35.

Malhotra, N. (1996). Marketing Research: An Applied Orientation (177). London: Great Britain. 
Morden, T. (2016). Principles of Strategic Management. Routledge.

Nunnally, J. C. (1994). Psychometric theory 3E. Tata: McGraw-hill education. Baskı.

OECD, Eurostat, Oslo Kılavuzu (2005). "Yenilik Verilerinin Toplanması ve Yorumlanması için İlkeler." TÜBiTAK 3.

Oke, A. (2007). "Innovation Types and Performance in Growing UK SMEs." International Journal of Operations \&amp; Production Management, Vol. 27 No. 7: 735-753.

Onağ, O.; Tepeci, M. (2016). “Örgütsel Öğrenme Kabiliyetinin Örgütsel Yenilikçilik Aracılığıyla Yeni Ürün ve İ̧̧letme Performansına Etkisi." İşletme İktisadi Enstitüsü Yönetim Dergisi, C. 80, 50-79.

Özdevecioğlu, M.; Biçkes, M. (2012). "Örgütsel Öğrenme ve İnovasyon İlişkisi: Büyük Ölçekli İşletmelerde Bir Araştırma." Erciyes Üniversitesi İktisadi ve İdari Bilimler Fakültesi Dergisi, C. 39, 19-45.

Patky, J. (2020). "The Influence of Organizational Learning on Performance and Innovation: A Literature Review." Journal of Workplace Learning, Vol. 32 No. 3: 229-242.

Podsakoff, P. M.; MacKenzie, S. B.; Moorman, R. H.; Fetter, R. (1990). "Transformational Leader Behaviors and Their Effects on Followers' Trust in Leader, Satisfaction, And Organizational Citizenship Behaviors." The Leadership Quarterly, Vol. 1 No. 2: 107-142.

Polatçı, S.; Sobacı, F. (2017). "Dönüşümcü ve Etkileşimci Liderlerin Çatışma Yönetim Strateji Tercihlerinin İncelemesi: Türkiye Genelinde Bir Araştırma." Ömer Halis Demir Üniversitesi İktisadi ve İdari Bilimler Fakültesi Dergisi, C. 10 S. 3: 27-40.

Santos, J. R. A. (1999). “Cronbach's Alpha: A Tool for Assessing the Reliability of Scales.” Journal of Extension, Vol. 37No. 2: 1-5.

Seçilmiş, C.; Kodaş, B.; Kodaş, D. (2017). “Örgütsel Öğrenme Yeteneği ve Yaratıcılık Süreci İlişkisi: Eskişehir'deki Mutfak." Journal of Tourism and Gastronomy Studies, C. 5 S. 3: 150-167.

Sendjaya, S.; Sarros, J. C. (2002). "Servant Leadership: Its Origin, Development, And Application in Organizations." Journal of Leadership \& Organizational Studies, Vol. 9 No. 2: 57-64.

Soto-Acosta, P.; Popa, S.; Palacios-Marqués, D. (2016). "E-Business, Organizational Innovation and Firm Performance in Manufacturing SMEs: An Empirical Study in Spain." Technological and Economic Development of Economy, Vol. 22 No. 6: 885-904.

Şentürk, F.; Durak, M.; Yılmaz, E.; Kaban, T.; Kök, N.; Baş, A. (216). “Dönüşümcü ve Etkileşimci Liderlik Tarzlarının Bireysel Yenilikçiliğe Etkisini Belirlemeye Yönelik Bir Araştırma." Mehmet Akif Ersoy Üniversitesi Sosyal Bilimler Enstitüsü Dergisi, C. 8 S. 17: 173-198.

Tamer, G. (2019). "The Effects of Organizational Culture on the Relationship of Organizational Learning and Innovation: A Research in a Private Health Institution." European Journal of Managerial Research (EUJMR), Vol. 3 No. 4: 27-44.

Tanyeri, M.; Fırat, A. (2005). "Rekabet Değişkeni Olarak Dış Kaynak Kullanımı (Outsourcing)”. Dokuz Eylül Üniversitesi Sosyal Bilimler Enstitüsü Dergisi, C.7 S. 3: 268-279.

Temel, E. (2016). “Dönüşümcü Liderlik ve Psikolojik Güçlendirme Arasındaki illişkide Örgütsel Özdeşleşmenin Aracılık Rolü: Nazilli'deki Kamu Kurumlarında Bir Uygulama." (Yüksek Lisans Tezi). Adnan Menderes Üniversitesi Sosyal Bilimler Enstitüsü, Aydın.

Wang, C.; Ahmed, P. (2004). "The Development and Validation of the Organizational Innovativeness Construct Using Confirmatory Factor Analysis." European Journal of Innovation lots, Vol. 7 No. 4: 303-313.

Waruwu, H.; Asbari, M.; Purwanto, A.; Nugroho, Y. A.; Fikri, M. A. A.; Fauji, A.; ... ; Dewi, W. R. (2020). "The Role of Transformational Leadership, Organizational Learning and Structure on Innovation Capacity: Evidence from Indonesia Private Schools." EduPsyCouns: Journal of Education, Psychology and Counseling, Vol. 2 No. 1: 378-397.

Woodman, R. W.; Sawyer, J. E.; Griffin, R. W. (1993). "Toward a Theory of Organizational Creativity." Academy of Management Review, Vol. 18 No. 2: 293-321.

Yazıcıoğlu, Y. ve Erdoğan, S. (2004). SPSS Uygulamalı Bilimsel Araştırma Yöntemleri. Ankara: Detay Yayıncılık

Yıldırım, M. H.; Sunman, G.; Oruç, Ş. (2018). "Kobi'lerde Uygulanan İnovasyon Stratejilerinde Yöneticilerin Dönüşümcü Liderlik Özelliğinin Rolü." İktisadi İdari ve Siyasal Araştırmalar Dergisi, C. 3 S. 7: 213-229.

Yiğit, S. (2015). "Inovasyon Rekabet Gücü Elde Etmeyi Daha da Önemlisi Bunu Sürdürmeyi Sağlar." Toprak İşveren Sendikası, C. 108 S. :1-10.

Zuñiga-Collazos, A. (2018). "Analysis of factors determining Colombia's tourist enterprise's organizational innovations." Tourism and Hospitality Research, Vol. 18 No. 2: 254-259. 


\section{Extended Summary}

\section{The Mediating Role of Organizational Learning in the Effect of Transformational Leadership on Organizational Innovation}

In the current century, the constantly changing and developing dynamic environmental conditions push the people responsible for the management in the enterprises to seek a more effective management. To achieve a sustainable competitive advantage, it is necessary to capture the change and transformation in the market. This is the business; It will require employees to make continuous innovation by taking advantage of their knowledge, skills, and creative efforts, and to increase the benefit they will gain by maximizing the efficiency of their resources. In this context, there is a need for transformational leaders who will realize this transformation, motivate employees, and pave the way for organizational learning and innovation. Transformational leaders can identify the dynamics of the current situation and determine new strategies for businesses. In this way, organizations can adapt to changing and developing environmental conditions and even be the change itself. The effect of transformational leadership on innovation increases with mediator factors such as organizational learning. A high degree of organizational learning will trigger better organizational innovation. In this way, businesses that encounter a new competitor every day in globalizing markets or struggle with the difficulties in the current competitive environment can develop options and methods that will provide competitive advantage. In this context, businesses can be able to respond effectively to changes in the market by maximizing the efficiency of their resources.

Leaders have a great role in ensuring change and innovation in businesses. When evaluated in terms of innovation, the different thinking and farsightedness of transformational leaders contribute to employees in their innovation strategy development processes. Transformational leaders are focused on change. Leaders are expected to anticipate the change that businesses need, plan business transformation, and manage this transition. Necessary innovations must be realized to achieve this transformation. These innovations are expected to contribute to performance. The impact of transformational leadership on business performance and innovation has been studied in various academic studies. When the studies are examined, it is found that transformational leadership influences organizational innovation or organizational learning.

In this study, the relationship between transformational leadership and organizational innovation, and the mediating role of organizational learning on this relationship are examined. As a result of the correlation and regression analysis, a positive and significant relationship was found between transformational leadership and organizational innovation. This result shows that organizational innovation can be explained by transformational leadership. For the sample in which the research was conducted, the transformational leadership feature contributes positively to the organizational innovation feature of the enterprise. As a result of the analysis conducted to examine the relationships between transformational leadership and organizational learning, it was found that transformational leadership has a positive and significant effect on organizational learning. This result shows that transformational leadership characteristics contribute positively to the learning ability of organizations.

Another result of the research is the relationship between organizational learning and organizational innovation. The results showed that organizational learning activities have a positive and significant effect on organizational innovation. This result shows that organizational learning contributes positively to the innovation activities of organizations for the sample in which the research was conducted. In addition to these relationships determined among the variables of transformational leadership, organizational learning and organizational innovation, the mediating role of organizational learning in the relationship between transformational leadership and organizational innovation was also analyzed. The results obtained reveal that transformational leadership contributes directly and indirectly to organizational innovation. The indirect effect of transformational leadership on organizational innovation is greater than its direct effect. This shows that transformational leadership leads to more organizational innovation through variable organizational learning. In the context of these results, the support of organizational learning as well as transformational leadership characteristics of the members of the organization will reveal organizational innovation.

Considering these holistic relationships between variables, it is obvious that businesses need to focus on innovation and transformation individually and organizationally by transforming organizational learning into an organizational culture through transformational leaders to achieve a sustainable competitive power in their competitive environment. The role of managers with transformational leadership characteristics is great for the formation of this learning culture and its establishment in the business. For businesses to achieve their goals in these difficult conditions, they will need to have leaders who can take the business out of a narrow framework and set new goals and strategies, construct and maintain internal and external environmental transformation.

Innovation is an important factor for businesses to gain competitive advantage. Although the effect of transformational leadership and organizational learning on innovation was investigated in this study, it cannot be said that only these factors influence innovation. In addition, many factors have an impact on innovation. In addition, the 
sample of the research is also an important constraint. It is thought that conducting more detailed studies to determine the factors that have an impact on the concept of innovation, expanding the sample in a sectoral or regional sense, and comparing it with the results of this and other studies in the literature, will contribute significantly to literature research. 